\title{
THE EFFECT OF INVESTMENT, WORKER, AND GOVERNMENT EXPENDITURE ON ECONOMIC GROWTH IN KUTAI KARTANEGARA REGENCY, INDONESIA
}

\author{
Iskandar, Aswin H. Raffles Juni, Suprapto Heru \\ Faculty of Economics and Business, University of Kutai Kartanegara, Indonesia \\ *E-mail: iskandar 76@rocketmail.com
}

\begin{abstract}
Economic growth is still the main goal and an important indicator of the success of regional economic development. Kutai Kartanegara regency has fluctuation level of economic growth and the economic growth on average over the study period is moderately high (approaching double digits/average $9.43 \%$ over the study period) compare with 4 districts/major cities in East Kalimantan as well as national economic growth. The purpose of this study is to determine how much the influence of investment, worker and government expenditure on economic growth of Kutai Kartanegara regency. This study uses theory of regional economic growth Solow-swan basing on Cobb Douglas production function with consideration of its ability to show the relationship balance between production result and combination of factor production used. The data use is Gross Regional Domestic Product (PDRB) data according to constant prices and the amount of worker that is published by Central Bureau of Statistics (BPS) of Kutai Kartanegara regency, government expenditure data based on Regional Budget (APBD) of Kutai Kartanegara regency and private investment data from Regional Investment Agency (BPMD) of Kutai Kartanegara regency began in 2007-2011 (time series). Regression analysis used is OLS with the assistance of EVIEWS 7 software. The study results show that private investment variable has negative effect but not significant to local economic growth and level of error is $\alpha 5 \%$, but worker variable has significant positive effect and government expenditure variable has positive effect but not significant.
\end{abstract}

\section{KEY WORDS}

Economic growth, government expenditure, private investment, worker.

In the era of regional autonomy, regional governments are at the forefront of national development and this is because regional government is more aware of things that are needed in development efforts, potential resources available to be used as material development and regional government directly interacts with the society, however development in the region should be in line with national development.

Economic development is a process that leads to the increase in real income per capita of a country over a long period accompanied by improvement in institutional system. From this sense a clear economic development has interpretations: 1) A process of change that occurs continuously, 2) Effort to raise per capita income, 3) The increase of per capita income that must take place in the long term, 4) Improvement in institutional system in all field (e.g. economic, politic, legal, social and culture). The system can be viewed from two aspects: improvement in the field of organizational aspect (institution) and improvement in the field of regulation (whether in formal legal or informal) (Arsyad, 1999: 11-12).

Regional economic development is a process by which regional governments and its society manage available resources and form a pattern of partnership between regional governments and private sector to create new jobs and stimulate the development of economic activity (growth) in the region. (Arsyad, 1999: 108).

Arsyad (1999: 108-109) continues, in order to create new jobs and stimulate the development of economic activity in the region, regional government is expected to be able to plan, establish related policy to reduce barriers and stimulate the growth of economic sector that implies in employee absorption in every economic sector.

One important benchmark in determining the success of economic development is economic growth that represents the real impact of development policy of the government in 
national, province, district and city. Economic growth is an indicator to illustrate economic performance in a region, economic growth in certain region is expressed in statistical figures which aims to simplify the region in making plan, decision as well as evaluation of the efforts made to improve economic performance of a region, in other words economic growth as one of the tools in economic policy strategy. The economic growth in a region is marked by a change to Gross Regional Domestic Product (PDRB) from year to year. Kutai regency economic performance can be seen in Table 1.

Table 1 - Economic Growth Rate of Five Regencies and Cities in East Kalimantan at Constant Prices in 2000

\begin{tabular}{|l|l|l|l|l|l|l|}
\hline Year & $\begin{array}{l}\text { PDRB } \\
\text { Kukar }\end{array}$ & $\begin{array}{l}\text { PDRB } \\
\text { Samarinda }\end{array}$ & $\begin{array}{l}\text { PDRB } \\
\text { Balikpapan }\end{array}$ & $\begin{array}{l}\text { PDRB } \\
\text { Kutai Timur }\end{array}$ & $\begin{array}{l}\text { PDRB } \\
\text { Paser }\end{array}$ & $\begin{array}{l}\text { PE } \\
\text { Kukar }\end{array}$ \\
\hline 2005 & 6.650 .958 & 9.272 .306 & 7.280 .058 & 10.943 .182 & 3.314 .261 & - \\
\hline 2006 & 7.437 .449 & 9.785 .160 & 8.029 .097 & 13.462 .726 & 3.709 .866 & $11,83 \%$ \\
\hline 2007 & 8.148 .612 & 10.073 .435 & 8.672 .738 & 14.656 .942 & 4.189 .093 & $9,56 \%$ \\
\hline 2008 & 8.678 .089 & 10.562 .675 & 9.551 .749 & 14.505 .373 & 4.486 .554 & $6,50 \%$ \\
\hline 2009 & 9.288 .665 & 11.039 .137 & 10.505 .448 & 15.310 .163 & 4.833 .229 & $7,04 \%$ \\
\hline 2010 & 10.421 .950 & 11.729 .245 & 11.303 .315 & 16.606 .371 & 5.670 .576 & $12,20 \%$ \\
\hline
\end{tabular}

Source: processed from East Kalimantan in the numbers of various editions.

Table 1 illustrates the economic growth in Kutai Kartanegara regency experiences moderately high fluctuation level compare to Samarinda, Balikpapan, East Kutai and Paser. In addition to experiencing moderately high fluctuation level, economic growth in Kutai Kartanegara regency in the period $2005-2010$ is big enough that amounted to $9.43 \%$ greater than the economic growth of 4 districts/major cities in East Kalimantan and the other above national economic growth ranging from 5 to $6 \%$ per year.

Investment is one important factor in regional economic growth. According to Sukirno (2000: 367-368) investment activity allows the society to continuously increase economic activity and employment, elevate national income and improve the prosperity of the society. This role comes from three important functions of investment activity, namely (1) investment is one component of aggregate expenditure, so that the increase in investment will increase aggregate demand, national income and employment opportunity; (2) the increase of capital goods as a result of investment will increase production capacity; (3) investment is always followed by the development of technology. This study uses investment from domestic investment (PMDN) and foreign investment (PMA). According to Table 2 it can be seen the growth of investment in Kutai Kartanegara regency has moderately high fluctuation and it tends to decrease.

Table 2 - The Number of Foreign Investment (PMA) and Domestic Investment (PMDN) Agreements Period $2005-2010$

\begin{tabular}{|c|c|c|c|c|}
\hline Year & Number of Projects & $\begin{array}{c}\text { Investment } \\
\text { (thousand \$ US) }\end{array}$ & Number of Projects & $\begin{array}{c}\text { Investment } \\
\text { (million Rupiah) }\end{array}$ \\
\hline 2005 & 13 & 259.444 & 1 & 682.200 \\
\hline 2006 & 16 & 915.474 & 7 & 14.688 .781 \\
\hline 2007 & 15 & 598.541 & 2 & 3.934 \\
\hline 2008 & 32 & 63.367 & 6 & 825.949 \\
\hline 2009 & 20 & 32.850 & 1 & 14.500 \\
\hline 2010 & 32 & 68.560 & 8 & 1.978 .668 \\
\hline Total & 128 & $1.938 .235^{*}$ & 25 & 18.194 .033 \\
\hline
\end{tabular}

Source: processed from Kutai Kartanegara in the numbers of various editions. 
Worker factor is one of the important factors that give effect to economic growth of a region other than investment. According to Todaro (2004: 93) population and workforce growth (AK) is traditionally regarded as one positive factor that spurs economic growth. The greater number of worker means the increase of production. It is still questionable whether the rapid population growth will give positive or negative impact on economic development. Furthermore, it is said that the positive and negative effects of population growth depends on the ability of regional economic system to absorb and productively utilize the added worker.

Table 3 - The Growth of Workforce in Kutai Kartanegara Regency Period 2005-2010

\begin{tabular}{|c|c|c|c|c|c|}
\hline \multirow{2}{*}{ Year } & \multicolumn{4}{|c|}{ Workforce } & \multirow{2}{*}{ Number of Workforce } \\
\cline { 2 - 5 } & Work & $\%$ & Find a Job & $\%$ & 213.744 \\
\hline 2005 & 187.885 & - & 25.859 & - & 213.774 \\
\hline 2006 & 197.387 & $5 \%$ & 16.387 & $-58 \%$ & 224.859 \\
\hline 2007 & 213.636 & $8 \%$ & 11.223 & $-46 \%$ & 253.751 \\
\hline 2008 & 228.821 & $7 \%$ & 24.930 & $55 \%$ & 263.668 \\
\hline 2009 & 233.667 & $2 \%$ & 30.001 & $17 \%$ & 294.620 \\
\hline 2010 & 260.640 & $10 \%$ & 33.980 & $12 \%$ & 209.202 \\
\hline Average & 188.862 & $6 \%$ & 20.340 & $-4 \%$ & \\
\hline
\end{tabular}

Source: processed from Kutai Kartanegara in the numbers of various editions.

Table 3 illustrates the rate of growth of people working from year to year to year increase quite well on average $6 \%$ per year and the number of people looking for work decrease on average $4 \%$ per year, it suggests opportunity to work or employment opportunity in Kutai Kartanegara regency is moderately large, in other words employment absorption in Kutai Kartanegara regency is moderately large.

Economic growth in the region cannot be separated from the role of regional government through government expenditure policy, by government expenditure it is expected to provide stimulation to other economic sectors and economic and social infrastructures development. Regional government expenditure is measured in total direct expenditure and indirect expenditure allocated in regional budget. The greater government productive expenditure means the greater economic level of a region (Wibisono, in Rustino, 2008: 7). Furthermore, in Rustino (2008: 7), Anaman (2004) states that government expenditure that is too small will harm economic growth, proportional government expenditure will increase economic growth and wasteful government expenditure will hamper economic growth. In general, government expenditure had positive impact on economic growth.

Kartananegara Kutai regency is one of the richest regencies in Indonesia, which is reflected in substantial Regional Budget (APBD) annually. Table 4 shows the realization of regional government expenditure from year to year, during the time this study is carried out, regional government increases expenditure on average of $8 \%$ per year with composition $48 \%$ is indirect expenditure and $51 \%$ is direct expenditure.

Table 4 - The Proportion of Indirect Expenditure and Direct Expenditure toward Regional Expenditure of Kutai Kartanegara Regency in 2005-2010 (in million Rupiah)

\begin{tabular}{|c|c|c|c|c|c|}
\hline Year & Indirect Expenditure & $\%$ & Direct Expenditure & $\%$ & Total Expenditure \\
\hline 2005 & $1.196 .464,89$ & 0,45 & $1.489 .523,90$ & 0,55 & $2.685 .988,79$ \\
\hline 2006 & $2.081 .403,05$ & 0,58 & $1.503 .512,37$ & 0,42 & $3.584 .915,42$ \\
\hline 2007 & $1.644 .093,28$ & 0,47 & $1.841 .469,56$ & 0,00 & $3.485 .562,84$ \\
\hline 2008 & $1.801 .919,24$ & 0,54 & $1.530 .882,86$ & 0,46 & $3.332 .802,10$ \\
\hline 2009 & $1.309 .898,32$ & 0,33 & $2.690 .401,82$ & 0,67 & $4.000 .300,14$ \\
\hline 2010 & $1.521 .223,05$ & 0,40 & $2.317 .939,13$ & 0,60 & $3.839 .162,19$ \\
\hline
\end{tabular}

Source: Ministry of Finance RI (www.kemenkeu.go.id) \& Annual Accountability Report (LKPJ) Regent of Kutai Kartanegara.

Problems of the Study. Kutai Kartanegara regency is one district which has moderately high economic growth on average $9.43 \%$ per year, it is possible by some factors they are 
private investment, worker and government expenditure. Based on this, there are problems as follows:

1. What is the effect of private investment to economic growth in Kutai Kartanegara regency?

2. What is the effect of worker to economic growth in Kutai Kartanegara regency?

3. What is the effect of government expenditure to economic growth in Kutai Kartanegara regency?

4. Are private investment, worker and government expenditure give effect to economic growth in Kutai Kartanegara regency?

Objectives of the Study. The objectives of this study are as follows:

1. To identify how much influence of private investment to economic growth.

2. To identify how much influence of worker to economic growth.

3. To know how big the effect of government expenditure on economic growth.

4. To know how much the influence of private investment, worker and government expenditure to economic growth in Kutai Kartanegara regency.

Significant of the Study. The significant of this study are as follows:

1. As an input (consideration) for the government of Kutai Kartanegara regency in formulating strategy and planning of economic development.

2. As a further reference for writers who writes thesis or other related papers on economic growth and development in Kutai Kartanegara regency.

\section{LITERATURE REVIEW}

Economic Growth. According Sukirno (2004: 9), economic growth is defined as the development of activities in economy which caused goods and services produced by community grows. Economic growth is one of the indicators that describe economic performance in a region.

According to economic growth neo-classical (Solow-swan) theory, the economic growth depends on the provision of additional factors (population, worker and capital accumulation) and the rate of technological progress. In other words, economic growth depends on the growth of population, worker and capital accumulation and technological progress. (Arsyad 1999: 62-64). Furthermore, according to this theory, the capital-output ratio (capital-output ratio $=\mathrm{COR}$ ) is mutable (the dynamic). In other words, to create a certain output it can use different amounts of capital with different amount of worker, according to the needs. Solow's theory is underlying the production function that is developed by Charles Cobb and Paul Douglas.

Investment. Based on economic theory, investment means purchase (and production) of capital goods which is not consumed but it is used for future production (goods production). (http://id.wikipedia.org/wiki/investasi).

According to Todaro (2004: 92), there are three major factors or components in economic growth of any nation, namely:

1. The accumulation of capital, it is including all forms or types of new investments that are invested in land, physical equipment, capital and human resources;

2. The development of the population followed by the growth of worker and their expertise;

3. Technological Progress

The accumulation of capital will be successful if some part or proportion of income is saved and invested to enlarge the product (output) and revenue in the future. To build this, it must switch the sources of current consumption and transfer it to investment in the form of "capital formation" to achieve greater production level. Investment in human resource development will enhance the ability of human resources, thus they become skilled experts who can facilitate productive activities.

Worker. According to the Central Bureau of Statistics (BPS), worker is a 15-year-old resident whose activity is to do the work with aim to obtain or help to earn income or profit and duration of work for at least one (1) hour per day continuously during the past week. 
According to Nicholson (2000: 160), the function of certain goods or service production (q) is $q=f(K, L)$ where $K$ is capital and $L$ is worker that shown maximum amount of goods/service that can be produced using alternative combination between $K$ and $L$ then if one of the inputs plus one additional unit and other inputs are considered constant it will cause an additional output produced. Additional output produced is called Marginal Physical Product. Furthermore it is said that the number of workers added continuously meanwhile another production factor is constant, it will initially show productivity but at a certain level will show a decline in productivity as well as after reaching the maximum output level of each addition of worker will reduce the output.

Government Expenditure. Government expenditure is part of the fiscal policy (Sukirno, 2004: 87) is a government action to regulate the economy by determining the amount of government revenue and expenditure each year that is reflected in State Budget (APBN) for national and Regional Budget (APBD) for regional. The purpose of this fiscal policy is stabilized the price, the level of output and employment and spur economic growth.

Hypotheses of the Study. From the problem formulation and review of the literature that has been raised tentative conclusions, it can be drawn as follows:

1. Private investment (foreign investment/PMA and domestic investment/PMDN) has significant positive effect on economic growth.

2. The number of workers has significant positive effect on economic growth.

3. Government expenditure has significant positive effect on economic growth.

4. Private investment (foreign investment/PMA and domestic investment/PMDN), worker and government expenditure simultaneously effect on economic growth.

Conceptual Definition. Economic growth is an indicator that describes economic performance in a region, the higher economic growth in a region indicates economic development in the region is quite well. Review from some theories previously, economic growth is influenced by private investment, worker and government expenditure.

\section{METHODS OF RESEARCH}

\section{Operational Definition:}

1. Economic growth is the development of activities in economy that lead to goods and service produced in society grows stated in Gross Regional Domestic Product (PDRB) at constant 2000 prices, Gross Regional Domestic Product (PDRB) which is intended in this study is non-oil (Y non-oil and gas) Gross Regional Domestic Product (PDRB) is expressed in units of rupiah.

2. Private investments is expenditure carried out by private sector to purchase capital goods and production equipment, private investment both foreign investment (PMA) and domestic investment (PMDN) in Kutai Kartanegara regency, expressed in units of rupiah.

3. Government expenditure is the realization of total regional government expenditure in Kutai Kartanegara regency (realization of Regional Budget/APBD), expressed in units of rupiah.

4. Worker is the number of working-age population (aged 15 and older) who are working, i.e. carry out economic activities that produce goods/service and the duration of work at least one hour per day on continuous during the past week in Kutai Kartanegara regency, expressed in units of person.

Type and Source of Data. According to its type, the data primarily used in this study is quantitative data. Gross Regional Domestic Product (PDRB) data, private investment, worker, and government expenditure obtained from Central Bureau of Statistics (BPS) of Kutai Kartanegara regency, Regional Investment Agency (BPMD) of Kutai Kertanegara regency, Regional Development Planning Agency (Bappeda) of Kutai Kertanegara regency.

Data Collection. The method in this study is documentation; the data is collected through written documents, especially in the form of archive and also including certain books, opinion, theory, proposition, or law and other related study issue. The data collection is done 
by approaching directly to the agency that issued the data/documents and visiting the website associated with the data /document required in the study.

Data Analysis Technique. Data analysis technique used in this study is using multiple regression with the smallest quadrant (ordinary least square) with the following equation:

$$
L n_{-} Y t L n_{-} I t=a 0+a 1+a 2+a 3 L n \_L t L n \_G t+e
$$

Where: Ln Yt: Economic growth in year t; Ln_It: Realization of Investment (PMA and PMDN) in year t; TKT Ln: Number of worker in year t; Ln_Gt: Actual government expenditure in year $\mathrm{t}$; e: erorr term.

In order to avoid this model from inefficiency/best linear estimator unbias/ BLUE, it is necessary to test the classical assumption, namely normality test, heterocedasticity test, autocorrelation and multicollinearity test. Normality test is used to test Jarque Bera (JB), when the value of $\mathrm{JB}>\mathrm{X}^{2}$ table, then the residual distribution is not normal, and vice versa. To detect heteroscedasticity, white test is used both for cross-term and no cross term with provisions $X^{2}$ value (value Obs* $R$ Square) $>$ Value $X^{2}$ table with $\alpha$, then do not pass heterocedasticity, and vice versa. To detect autocorrelation using Breusch-Godfrey with provisions if the value $X^{2}$ count $>X^{2}$ table, the model have autocorrelation probem, and vice versa. To test multicolinearity i.e. by comparing the $R^{2}$ primary regression model with $R^{2}$ regression model between independent variables, with the terms $R^{2}>R^{2}{ }_{11}, R^{2}{ }_{12}, R^{2}{ }_{13}$, then it is free from muliticolinearity, and vice versa. To test the coefficient significant simultaneously by using $\mathrm{F}$ test and the partial by using $t$ test.

\section{RESULTS AND DISCUSSION}

Data Analysis. Classical Assumption Test results using EVIEWS 7 as follows:

1. Normality test, JB 0.345419 value while the value $X^{2}$ table with the $\mathrm{df}-1$, sig $\alpha=0.05$ at 7.81. This gives conclusions $Y$ oil and gas models and $Y \_$non oil and gas residual distributed normally.

2. Heterokedastisitas test, value (Obs ${ }^{*} \mathrm{R}$ square) with crossterm and value of 6.933671 (Obs* $R$ square) no crossterm of 5.616950 while the $X^{2}$ table with df- 1 , sig $\alpha=0.05$ at 7.81. The conclusion is there is no heterocedasticity problem to the model.

3. Test autocorrelation value $\left(\mathrm{Obs}^{*} \mathrm{R}\right.$ square) is 4.062781 and $\mathrm{X}^{2}$ table with the $\mathrm{df}-1$, sig $\alpha=0.05$ at 7.81 . The conclusion is there is no problem in serial correlation to equation model.

4. Multikolinieritas test, the value of $R^{2}$ primary model is greater than $R^{2}$ between independent variables $(0.993563>0.712580 ; 0.810024 ; 0.558508)$. The conclusion equation model is free of problem.

Data obtained after being processed by EVIEWS 7 as follows:

$$
\begin{aligned}
& L n \_Y_{t}=a_{0}+a_{1} L n \_I_{t}+a_{2} L n \_L s_{t}+a_{3} L n \_G_{t}+e \\
& L n_{-} Y_{t}=-3.162092-0.006421 L n \_I s+1.397414 L n_{t} L_{t}+0.133534 L_{-} G_{t}+e \\
& \text { Std. Error }=1.4784980 .009316 \quad 0.151669 \quad 0.105875 \\
& \text { t_hitung }=-2.138720-0.689226 \quad 9.213585 \quad 1.261244 \\
& R^{2}(R \text { square })=0.993563 \\
& \text { F-statistic }=154.3513
\end{aligned}
$$

The above data can be concluded as follows:

1. F-test describes F-statistic $>\mathrm{F}$ table, then, it causes $\mathrm{Ho}$ is refused and $\mathrm{Ha}$ is accepted, or the conclusion of investment, worker and government expenditure simultaneously have a significant influence on economic growth in Kutai Kartanegara regency during the period 2005 to 2011. 
2. Test $t$ describes private investment variable has no significant effect on economic growth, worker variable significantly influence economic growth and government expenditure variable is not significant to economic growth.

\section{DISCUSSION OF RESULTS}

Based on the data that has been presented previously, the constant coefficient was 3.162092; this showed the indication of decrease in economic growth that was $3.16 \%$ when independent variable was considered constant. Worker variable showed moderately high elasticity to economic growth, followed by government expenditure variable and private investment. Concrete explanation was as follows:

$a_{1}=-0.006421, \mathrm{t}$ test ${ }_{\text {investment }}=$ not significant investment; it showed that private investment has negative effect but not significant to economic growth or in other words an increase of $1 \%$ in private investment will decrease $0.064 \%$ of economic growth in Kutai Kartanegara regency stated in Gross Regional Domestic Product (PDRB) non-oil on constant prices 2000 period 2005 to 2011 but not it was not give significant effect (ceteris paribus, or another variable was considered constant). This is due to realization of investment data Regional Investment Agency was incomplete. According to BPMD supervision section, incomplete realization of investment data owned by the government through Regional Investment Agency (BPMD) because there were companies that did not report their realization of investment activities to the government and it was suspected that negative effect of investment was caused by the region that did not provided favorable climate for domestic or foreign investor. The result was similar with the previous study (Jamani Sodik and Didi Nurhayadin 2005: 167) that foreign investment (PMA) and domestic investment (PMDN) have no effect on economic growth after regional autonomy period even the coefficient tended to be negative, it also showed that the region has not given favorable climate for domestic or foreign investor.

$a_{2}=1.397414, t$ test worker $=$ significant; it showed the worker has significant positive effect on economic growth or in other words an increase of $1 \%$ of worker would increase $1.397 \%$ economic growth in Kutai Kartanegara regency stated in Gross Regional Domestic Product (PDRB) of non-oil on constant price in 2000 period 2005 to 2011 (ceteris paribus, or another variable was considered constant).

$\mathrm{a}_{3}=0.133534, \mathrm{t}$ test government expenditure $=$ not significant; it showed the government expenditure has positive effect but not significant to economic growth, or in other words an increase of $1 \%$ in government expenditure would only increase $0.136 \%$ economic growth in Kutai Kartanegara regency stated in Gross Regional Domestic Product (PDRB) of non-oil on constant price in 2000 period 2005 to 2011 (ceteris paribus, or another variable was considered constant). The effect of government expenditure on economic growth was relatively small it was suspected to has correlation to the proportion of indirect expenditure of government that was on average $45 \%$ of total expenditure, or only $55 \%$ of total expenditure was used to finance regional development, it made regional financial development was not maximum. The result was also similar to Anaman (2004) statement in Dedy Rustino (2008: 7) who stated that small government expenditure would harm to economic growth, proportional government expenditure would increase economic growth and wasteful government expenditure would hamper economic growth.

\section{CONCLUSION AND SUGGESTIONS}

Based on analysis and study that have been done it can be conclude that investment, worker, and government expenditure simultaneously gave effect to economic growth without oil and gas in Kutai Kaetanegara regency. Nevertheless, only worker who has significant positive effect on economic growth without oil and gas in Kutai Kartanegara regency while government expenditure has positive effect but not significant and investment has negative effect but no significant effect on economic growth without oil and gas in Kutai Kartanegara regency. 
The negative effect of investment on economic growth in Kutai Kartanegara was caused by realization of investment data owned by Regional Investment Agency can be said it was incomplete. According to Regional Investment Agency (BPMD) supervision, incomplete realization of investment owned by the government through Regional Investment Agency (BPMD) was caused by many companies did not report their realization of investment activities to the government. In addition to incomplete data on realization of investment, it was reasonably suspected the negative effect was caused by the region that did not provide favorable climate for domestic or foreign investor (but it needed to be studied further).

From the analysis conducted there are some suggestions for policy makers (decision maker) and stakeholders, among others:

Policy - a policy that can be taken by the government to optimize the investment activities such as:

- Applying the policy by giving reward to companies that report realization of investment activities on a regular basis and provides punishment for companies that do not report realization of investment activities.

- Identify potential investment in investment map or regional investment profile

- Coordinating with other government agencies related to investments either vertically or horizontally.

- Developing human resources in the government, businessman, and worker in the region.

- Increasing investment promotion activities through diversification of type and quality of investment information services.

It has been known that worker has significant influence on economic growth in Kutai Kertanegara regency, beside worker the closest aspect of society welfare (related to distribution of income) and therefore the problem regarding to worker is very important to be concerned by implementing policies for the worker welfare, the policy that can be taken including:

- Improving the quality of human resources through education and skills program.

- There should be a policy for worker planning in macro and micro in order to provide vast employment opportunities for the society.

- Improving intensity in supervision system of the companies that use contract worker (outsourcing). In practice, there are many companies suspected in Kutai Kertanegara regency violate the provisions of articles 59 and 64 Law No. 13 Year 2003 on worker.

Based on the analysis of the results of the studies that have been done, government expenditure does not significantly gives effect to non-oil economic growth in Kutai Kartanegara regency therefore the regional government should carry out a review of the government expenditure, the policy that can be taken, such as:

- Official travel system for civil servants should be strict, because according to Minister of Finance there is swelling on civil servants official travel budget postal in 2013 (Tempo.co bisnis, Thursday 13 September 2012). The policy regarding official travel system absolutely must be done considering the inefficient government expenditure in giving effect to economic growth and the expenses of official travel is not proportional compare to the result obtained from official travel itself.

- The policy of government expenditure as outlined in Regional Budget (APBD) should be more directed to the development of potential economic sectors in optimizing economic growth.

\section{REFERENCES}

1. Anonymous, Kutai Kartanegara Dalam Angka tahun 2006, 2007, 2008, 2009, 2010, 2011, Indonesian Statistical Bureau of Kutai Kartanegara Regency.

2. 2005, Realisasi APBD Tahun 2005, Ministry of Finance of the Republic of Indonesia. www.kemenkeu.go.id. 
3. 2006, Laporan Keterangan Pertanggung Jawaban Bupati Kutai Kartanegara TA 2006, 2007, 2008, 2009, 2010, 2011, BAPPEDA Kutai Kartanegara

4. Arsyad, Lincolin. 1999, Ekonomi Daerah, $2^{\text {nd }}$ Edition, BPFE, Yogyakarta.

5. 1999, Ekonomi Pembangunan, $4^{\text {th }}$ Edition, STIE YKPN, Yogyakarta.

6. Nicholson, Walter. 2000, Mikroekonomi Intermediate, 8th Edition, Erlangga Publisher, Jakarta

7. Rustino, Deddy. 2008, Analisis Pengaruh Investasi, Tenaga Kerja dan Pengeluaran Pemerintah Terhadap Pertumbuhan Ekonomi Jawa Tengah, Thesis. Diponegoro Univeristy of Semarang

8. Sukirno, Sadono. 2000, Makroekonomi Modern: Perkembangan Pemikiran Dari Klasik Hingga Keynesian Baru, Raja Grafindo Pustaka

9. 2004, Makroekonomi, $3^{\text {rd }}$ Edition, Rajawali Pers Publisher, Jakarta.

10. Todaro, Michael P .2004, Pembangunan Ekonomi Dunia Ketiga, $8^{\text {th }}$ Edition, Erlangga Publisher, 2004.

11. Wikipedia Indonesia, Pengertian Investasi, http://id.wikipedia.org/wiki/investasi 